\title{
(2) OPEN ACCESS \\ Acute respiratory distress syndrome precipitated by granulocyte colony-stimulating factor in undiagnosed Pneumocystis jirovecii pneumonia
}

\author{
Christopher Doig 주 , Rachel Cooke, Chyn Chua, Teresa Leung
}

Department of Haematology, Northern Health Research and Education, Epping, Victoria, Australia

\section{Correspondence to \\ Dr Christopher Doig: cwdoig@gmail.com}

Accepted 2 December 2021

Check for updates

(c) BMJ Publishing Group Limited 2022. Re-use permitted under CC BY-NC. No commercial re-use. See rights and permissions. Published by BMJ.

To cite: Doig C, Cooke $\mathrm{R}$ Chua $\mathrm{C}$, et al. BMJ Case Rep 2022;15:e242316. doi:10.1136/bcr-2021242316

\section{SUMMARY}

We present the case of a 62-year-old man with rheumatoid arthritis who developed a leukaemoid reaction and acute respiratory distress syndrome (ARDS) following granulocyte colony-stimulating factor (G-CSF) administration that had been given to treat neutropenia secondary to methotrexate and leflunomide toxicity. Later it was established that he had Pneumocystis jirovecii pneumonia, which was treated to complete resolution with a course of corticosteroids and antibiotics. This case highlights the potential risk of G-CSF administration in an immune compromised individual in the midst of bone marrow recovery in the context of active infection. Recognition of immune escape syndromes is vital and requires an understanding of potential triggers and risk factors.

\section{BACKGROUND}

Granulocyte and granulocyte-macrophage colony stimulating factors (G-CSF and GM-CSF) cause myelopoiesis with the production of innate immune cells (monocytes, macrophages, dendritic cells and granulocytes) from bone marrow progenitor cells. Clinically, G-CSF can be utilised in patients to shorten the duration of neutropenia postchemotherapy, and thereby reduce the potential of developing life-threatening sepsis. ${ }^{1}$

Pulmonary toxicity has been infrequently linked to G-CSF use. ${ }^{2}$ It is typically characterised by cough, pulmonary oedema and, rarely, acute respiratory distress syndrome (ARDS). Such adverse events have been described in cases related to concomitant chemotherapeutic agents with independent pulmonary toxicities, most notably bleomycin ${ }^{3}$; however, there are relatively few cases in which G-CSF administration, or the resultant immune reconstitution, are linked to the development of ARDS. ${ }^{45}$

We report the case of ARDS precipitated by G-CSF used to treat methotrexate-induced myelosuppression, coinciding with the diagnosis of Pneumocystis jirovecii pneumonia.

\section{CASE PRESENTATION}

A 62-year-old man presented to the emergency department with a fall, and described 6 weeks of lethargy, night sweats and mouth ulcers, as well as a $10 \%$ weight loss over 6 months.

His history was most significant for rheumatoid arthritis, type 2 diabetes mellitus, controlled hypertension, transient ischaemic attack and an excised squamous cell carcinoma of the skin. He was a former smoker with a 20 pack-year history. Relevant medications for his rheumatoid arthritis included methotrexate $20 \mathrm{mg}$ weekly, folic acid $5 \mathrm{mg}$ weekly, leflunomide $20 \mathrm{mg}$ daily and prednisolone $5 \mathrm{mg}$ daily, the doses of which had been constant for approximately 18 months. In addition, he had been recently treated for vitamin B12 deficiency by his general practitioner.

Initial laboratory investigations revealed a macrocytic anaemia (haemoglobin $95 \mathrm{~g} / \mathrm{L}$, mean corpuscular volume $101 \mathrm{fL}$ ), leucopenia (absolute neutrophil count (ANC) $1.0 \times 10^{9} / \mathrm{L}$ and lymphocyte count $0.5 \times 10^{9} / \mathrm{L}$ ), deranged liver function tests and acute kidney injury. The initial platelet count was normal at $171 \times 10^{9} / \mathrm{L}$. $\mathrm{C}$ reactive protein (CRP) and lactate dehydrogenase $(\mathrm{LDH})$ were not elevated and a whole body CT scan was unremarkable. Vitamin B12 levels were adequate, consistent with recent replacement. His methotrexate was ceased, and on the third day of his admission he was presumptively treated for methotrexate toxicity with calcium folinate rescue; however, serum methotrexate levels subsequently returned as undetectable.

Over the following 3 days of his admission, he developed new thrombocytopenia (with a nadir of $76 \times 10^{9} / \mathrm{L}$ on day 3 ) and progressive anaemia requiring red cell transfusion. He also developed fever with dry cough and was commenced on intravenous ceftriaxone and flucloxacillin to treat sepsis of unknown origin. A chest radiograph was unremarkable at the time and he did not require any oxygen supplementation. ANC fell further to $0.7 \times 10^{9} / \mathrm{L}$ and he was administered a single dose of subcutaneous filgrastim $300 \mu \mathrm{g}$ on day 5 .

The following day, his clinical condition deteriorated acutely with persistent fevers and progressive respiratory compromise requiring high-flow oxygen supplementation. Hypoxaemia was confirmed on arterial blood gas. Chest auscultation revealed diffuse coarse crackles and CT chest demonstrated new changes of bilateral alveolar infiltrates (figure 1) without evidence of cardiac failure. As such, the diagnostic criteria for ARDS were satisfied. ${ }^{6}$ Serial nose and throat swabs were negative for SARS-CoV-2 and other common respiratory viruses. Blood tests revealed an acute phase reaction with CRP $106 \mathrm{mg} / \mathrm{L}$, albumin $19 \mathrm{~g} / \mathrm{L}, \mathrm{LDH}$ $316 \mathrm{U} / \mathrm{L}$ and ferritin $7060 \mu \mathrm{g} / \mathrm{L}$, and a doubling of ANC to $1.4 \times 10^{9} / \mathrm{L}$ and total white blood cell count of $2.2 \times 10^{9} / \mathrm{L}$. Blood film examination revealed a left shift with circulating intermediate myeloid cells and a population of large immature cells suspicious for blasts (comprising 4\% of nucleated cells).

Over the following 3 days, his clinical condition remained critical, requiring the maximal 


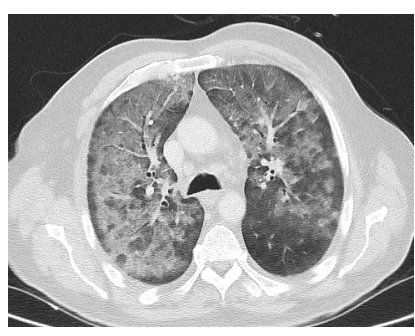

Figure 1 Chest CT demonstrating diffuse alveolar infiltrates.

oxygenation that could be provided noninvasively. The serological parameters continued to worsen over this time with progressively marked hyperferritinaemia and increased LDH (ferritin peaking at $23999 \mu \mathrm{g} / \mathrm{L}$ and $\mathrm{LDH}$ at $1445 \mathrm{U} / \mathrm{L}$ ) (figure 2), along with the development of moderate hepatocellular damage. To investigate for haemophagocytic lymphohistiocytosis (HLH) and a possible underlying haematological malignancy, a bone marrow aspirate and trephine were performed that demonstrated hypocellularity with left-shifted granulopoiesis but no excess of blasts, and there was no morphological evidence of haemophagocytosis.

Given the chronicity of immunosuppression with lymphocytedepleting therapies and progressive respiratory failure, an induced sputum was performed that identified $P$. jirovecii on PCR testing. A diagnosis of $P$. jirovecii pneumonia and ARDS was made; the latter exacerbated, or even potentially as a direct result of G-CSF administration and the consequential inflammatory response.

\section{DIFFERENTIAL DIAGNOSIS}

Prior to the bone marrow biopsy, the differential diagnoses being considered included HLH, potentially as a consequence of an underlying haematological malignancy such as acute leukaemia. Secondary causes of HLH or macrophage activation syndrome and respiratory failure were also considered, particularly COVID-19 infection, which can produce a similar syndrome due to cytokine storm.

\section{TREATMENT}

In addition to temporary supplemental oxygen, the patient had his antibiotic treatment rationalised and was prescribed trimethoprim/sulfamethoaxazole $320 / 1600 \mathrm{mg}$ orally three times daily for 4 weeks, and a tapering course of oral prednisolone.

\section{OUTCOME AND FOLLOW-UP}

Over the following week, his cough resolved, oxygen requirement diminished and his liver and renal function recovered. Full blood examination normalised following an initial neutrophilia (ANC $24.8 \times 10^{9} / \mathrm{L}$ ), and ferritin and LDH improved (figure 2). $\mathrm{He}$ was discharged with a weaning course of steroids over
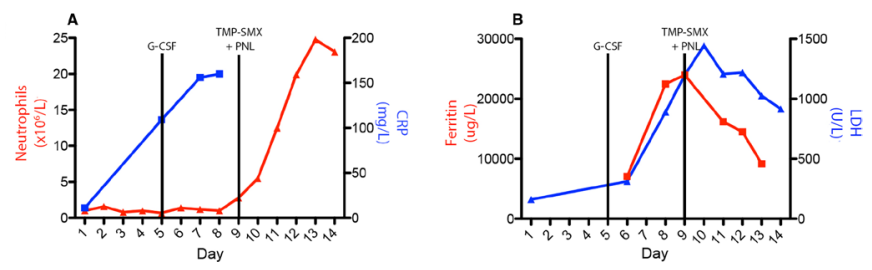

Figure 2 Inflammatory markers during hospital admission (A) neutrophil count and $\mathrm{C}$ reactive protein (CRP), (B) ferritin and lactate dehydrogenase (LDH).
4 weeks, tapering to $5 \mathrm{mg}$ daily until an alternative treatment for rheumatoid arthritis was selected, and he made a complete recovery.

\section{DISCUSSION}

Syndromes such as ARDS, as well as systemic inflammatory response syndrome (SIRS) and haemophagocytic syndrome, result from overactivation of a dysregulated immune response and can be rapidly progressive and life-threatening. These types of immune escape syndromes are infrequently reported in association with G-CSF use.

With hindsight, one can speculate that in the case presented, the individual's bone marrow was already recovering from methotrexate and leflunomide toxicity (and potentially megaloblastic anaemia due to vitamin B12 deficiency) at the time of presentation at the emergency department. G-CSF was later administered due to concern for his progressive neutropenia and deteriorating clinical state but would not usually be advised in the absence of severe neutropenia (typically ANC $<0.5 \times 10^{9} / \mathrm{L}$ ).

The development of ARDS in association with G-CSF-assisted neutrophil recovery has been described in a case series of patients with pre-existing, radiologically evident infections while receiving cancer chemotherapy. ${ }^{7}$ A further case series described this phenomenon occurring in patients with the HLA-B51 and HLA-B52 antigens while receiving conventional chemotherapy or allogeneic haematopoietic stem cell transplant. ${ }^{8}$ Reports of G-CSF-induced pulmonary toxicity independent of infections and malignancy are very rare, with only two case reports found. ${ }^{9} 10$

Administration of granulocyte and macrophage colonystimulating factors, while useful, should be treated with caution as the upregulation of cytokines that increase alveolar permeability or neutrophil influx (such as TNF- $\alpha$, IL-1 $\beta$ and IL-8) can exacerbate acute lung injury. Activated neutrophils have been implicated in the development of ARDS via effects on microvascular injury and vascular permeability. ${ }^{9}$ Furthermore, increasing concentration of endogenous G-CSF has been associated with the severity of lung injury in ARDS and acute lung injury, both in bronchioalveolar lavage fluid (BALF) and serum, in addition to elevations in BALF IL-8. ${ }^{10} 11$

In the era of COVID-19, an understanding of the mechanisms of tissue damage in lung disease, and the role that the innate immune system plays in this, is increasingly important.

\section{Learning points}

Exogenous granulocyte-macrophage colony stimulating factor (G-CSF) may exacerbate, or increase the risk of, pulmonary injury in patients with pre-existing or emerging respiratory disease.

- Localising the source(s) of infection can be difficult in immunosuppressed patients and Pneumocystis jirovecii pneumonia should always be considered in any patient with prolonged immunosuppression (especially with lymphopenia and/or corticosteroid use) and with respiratory symptoms.

- Balancing the risks of prolonged immunosuppression against the risk of immune overactivity with G-CSF administration presents a challenge that must take into consideration changing clinical findings. Caution should be exerted in those individuals with a recovering bone marrow postinsult, in whom fuelling the innate immune response may prove pathogenic especially where there is concurrent infection. 
The therapeutic use of G-CSF or GM-CSF in COVID-19 infection remains unclear but its use would seem counterintuitive given the promising trials with suppression of inflammatory cascades via inhibition of IL-1 and IL- 6 with anakinra and sarilumab, respectively. ${ }^{1213}$ A recent randomised trial suggested that GM-CSF administration may result in reduced rates of death or critical illness $;^{14}$ however, several cases have been described in which patients with COVID-19 have suffered respiratory deterioration following GM-CSF. ${ }^{15} 16$

This case highlights the potential risk of G-CSF administration in an immune compromised individual in the midst of bone marrow recovery in the context of active infection. Recognition of immune escape syndromes is vital and requires an understanding of potential triggers and risk factors.

Contributors CD primarily drafted the manuscript and compiled clinical and laboratory information, with primary supervision from RC. TL and CC critically reviewed the information. All authors substantially reviewed, commented on and approved the final version.

Funding The authors have not declared a specific grant for this research from any funding agency in the public, commercial or not-for-profit sectors.

Competing interests None declared.

Patient consent for publication Consent obtained directly from patient(s).

Provenance and peer review Not commissioned; externally peer reviewed.

Open access This is an open access article distributed in accordance with the Creative Commons Attribution Non Commercial (CC BY-NC 4.0) license, which permits others to distribute, remix, adapt, build upon this work non-commercially, and license their derivative works on different terms, provided the original work is properly cited and the use is non-commercial. See: http://creativecommons.org/ licenses/by-nc/4.0/.

Case reports provide a valuable learning resource for the scientific community and can indicate areas of interest for future research. They should not be used in isolation to guide treatment choices or public health policy.

\section{ORCID iD}

Christopher Doig http://orcid.org/0000-0002-7105-241X

\section{REFERENCES}

1 Maher DW, Lieschke GJ, Green M, et al. Filgrastim in patients with chemotherapyinduced febrile neutropenia. A double-blind, placebo-controlled trial. Ann Intern Med 1994;121:492-501.

2 Iki S, Yoshinaga K, Ohbayashi Y, et al. Cytotoxic drug-induced pneumonia and possible augmentation by G-CSF--clinical attention. Ann Hematol 1993;66:217-8.

3 Adachi K, Suzuki M, Sugimoto T, et al. Effects of granulocyte colony-stimulating factor (G-CSF) on bleomycin-induced lung injury of varying severity. Toxicol Pathol 2003;31:665-73

4 Ruiz-Argüelles GJ, Arizpe-Bravo D, Sánchez-Sosa S, et al. Fatal G-CSF-induced pulmonary toxicity. Am J Hematol 1999;60:82-3.

5 Arimura $\mathrm{K}$, Inoue $\mathrm{H}$, Kukita T. Acute lung injury in a healthy donor during mobilization of peripheral blood stem cells using granulocyte-colony stimulating factor alone. Haematologica 2005;90:e27-9.

6 Matthay MA, Ware LB, Zimmerman GA. The acute respiratory distress syndrome. J Clin Invest 2012;122:2731-40.

7 Karlin L, Darmon M, Thiéry G, et al. Respiratory status deterioration during G-CSFinduced neutropenia recovery. Bone Marrow Transplant 2005;36:245-50.

8 Takatsuka H, Takemoto Y, Mori A, et al. Common features in the onset of ARDS after administration of granulocyte colony-stimulating factor. Chest 2002;121:1716-20.

9 Ware LB, Matthay MA. The acute respiratory distress syndrome. N Engl J Med 2000;342:1334-49.

10 Wiedermann FJ, Mayr AJ, Kaneider NC, et al. Alveolar granulocyte colony-stimulating factor and $\alpha$-Chemokines in relation to serum levels, pulmonary neutrophilia, and severity of lung injury in ARDS. Chest 2004;125:212-9.

11 Matute-Bello G, Liles CW, Radella F, et al. Modulation of neutrophil apoptosis by granulocyte colony-stimulating factor and granulocyte/macrophage colony-stimulating factor during the course of acute respiratory distress syndrome. Crit Care Med 2000;28:1-7.

12 Cavalli G, De Luca G, Campochiaro C, et al. Interleukin-1 blockade with high-dose anakinra in patients with COVID-19, acute respiratory distress syndrome, and hyperinflammation: a retrospective cohort study. Lancet Rheumatol 2020;2:e325-31.

13 Della-Torre E, Campochiaro C, Cavalli G, et al. Interleukin-6 blockade with sarilumab in severe COVID-19 pneumonia with systemic hyperinflammation: an open-label cohort study. Ann Rheum Dis 2020;79:1277-85.

14 Cheng L-L, Guan W-J, Duan C-Y, et al. Effect of recombinant human granulocyte colony-stimulating factor for patients with coronavirus disease 2019 (COVID-19) and lymphopenia: a randomized clinical trial. JAMA Intern Med 2021;181:71-8.

15 Taha M, Sharma A, Soubani A. Clinical deterioration during neutropenia recovery after G-CSF therapy in patient with COVID-19. Respir Med Case Rep 2020;31:101231.

16 Nawar T, Morjaria S, Kaltsas A, et al. Granulocyte-colony stimulating factor in COVID-19: is it stimulating more than just the bone marrow? Am J Hematol 2020:95:e210-3.

Copyright 2022 BMJ Publishing Group. All rights reserved. For permission to reuse any of this content visit

https://www.bmj.com/company/products-services/rights-and-licensing/permissions/

BMJ Case Report Fellows may re-use this article for personal use and teaching without any further permission.

Become a Fellow of BMJ Case Reports today and you can:

- Submit as many cases as you like

- Enjoy fast sympathetic peer review and rapid publication of accepted articles

- Access all the published articles

Re-use any of the published material for personal use and teaching without further permission

Customer Service

If you have any further queries about your subscription, please contact our customer services team on +44 (0) 2071111105 or via email at support@bmj.com.

Visit casereports.bmj.com for more articles like this and to become a Fellow 